\title{
Formação Profissional Continuada
}

\section{Dra. Wilma de Lara Bueno'}

Foi no final da década de 1980 que aceitei, como professora do Ensino Fundamental, o convite da Secretaria Municipal de Educação para compor o grupo de docentes que iria constituir a Coordenação do Ensino de História do Município de Curitiba. Eram tempos preciosos da redemocratização do Brasil, ao sabor do movimento das "Diretas Já" e aumentava a expectativa e a emoção das pessoas da minha geração de votarem, pela primeira vez, para eleger o presidente do Brasil, o que ocorreu somente em 1989.

A década foi intensa e tenho orgulho de tê-la vivido e, particularmente, a compartilhado com um grande número de profissionais da educação, entre pedagogos, historiadores, geógrafos, sociólogos, cujos nomes eu guardo com carinho como marca de um tempo de muitas esperanças e conquistas, ainda que difíceis. Intelectuais, professores, pais, entre muitos representantes sociais, integraram movimentos pela gestão da escola pública de qualidade, com vistas ao combate da evasão escolar e à incorporação de conteúdos significativos nas propostas curriculares.

Foi um período muito rico no campo da Pedagogia, tendo Paulo Freire como a nossa referência intelectual marcante. Com ele aprendemos a exercitar o conceito da práxis, a partir das leituras de suas obras: "É exatamente esta capacidade de atuar, operar, transformar a realidade de acordo com as finalidades propostas pelo homem, à qual está associada sua capacidade de refletir, que o faz um ser da práxis" (FREIRE, 1979, p. 17).

Com o intuito de atender às exigências democráticas, as secretarias municipais mobilizaram suas equipes para reformulação dos currículos e elaboração dos projetos pedagógicos, entendidos como os norteadores de todas as atividades escolares. Nessa perspectiva, ocorreu um trabalho que envolveu escolas, professores e representantes das comunidades da rede municipal de ensino. Seminários e debates foram organizados pelos professores da Secretaria Municipal de Educação para conhecer, analisar, interpretar as tendências progressistas com foco na concepção denominada Pedagogia Histórico-Crítica. Os estudos intensos passavam a fundo os conceitos de L. S. Vygostky, Antonio Gramsci, explorando as obras de Paolo Nosella e Dermeval Saviani. Equipes de trabalho das diversas as áreas de ensino buscavam estratégias para traduzir os conceitos da teoria dialética da produção do conhecimento em práticas pedagógicas.

Como suporte reflexivo, construíamos quadros comparativos das tendências pedagógicas concebidas ao longo da história, dando ênfase, particularmente, às mudanças do foco

\footnotetext{
${ }^{1}$ Coordenadora do Núcleo de Docentes e Pesquisadores (NDP) da Faculdade Unina. E-mail: wilma.bueno@ unina.edu.br
} 
do aluno passivo para o sujeito ativo e construtor de sua história; da transmissão do conhecimento pelo professor para sua construção, considerando a relação professor-aluno como sujeitos da história e produtores do saber.

No campo do ensino da História, em especial, ocorreu uma verdadeira revolução dos "Estudos Sociais" presentes na época da ditadura civil-militar, para o ensino da História e da Geografia, as quais, mesmo permanecendo articuladas, apresentavam especificidades, exigindo autonomia e metodologias próprias.

Entre muitas exigências, as reflexões, procedentes das novas concepções pedagógicas, revelavam a importância da renovação curricular e sua relação para a formação crítica do aluno; alertavam para a importância de se articular os conteúdos trabalhados na escola com a mais recente produção científica, preocupando-se, fundamentalmente, com a transposição dos conhecimentos acadêmicos para o saber escolar.

Metodologicamente, incorporávamos procedimentos fundamentados na concepção dialética da história, buscando-se trabalhar um ensino-aprendizagem que estabelecesse um diálogo profícuo entre o particular e o geral; o todo e as partes (o todo não é a soma das partes), situando a história de vida do aluno na realidade social, política, econômica e cultural e sua relação com as esferas mais amplas. Nessa dinâmica, as metodologias problematizavam o saber acumulado historicamente e propunham situações para se pensar, como o conhecimento foi construído coletivamente por todas as pessoas, dos mais diversos grupos sociais, culturas e sociedades.

Enfim, foi um tempo de grandes transformações no cenário educacional, com a renovação das concepções de ensino, das abordagens metodológicas e do elenco dos conteúdos das matrizes curriculares.

Para ser breve, foi com certa inquietação que começamos a selecionar temáticas/conteúdos da história da humanidade e do Brasil para as propostas pedagógicas do Ensino Fundamental. Procurava-se denunciar o esvaziamento dos conteúdos tradicionais, dos chamados "círculos concêntricos", os quais contemplavam temas como a família, a escola, o bairro e o município sem, no entanto, estabelecer-se o compromisso da construção do pensamento reflexivo-crítico, o que deixava de contribuir para a formação do aluno, construção de sua identidade e vivência da cidadania.

Em que pesem as contradições, uma vez que doravante muitas propostas do ensino de História tornaram-se conteudistas, os passos metodológicos propunham o rompimento com as aulas expositivas e criavam estratégias problematizadoras, a partir do cotidiano do aluno. Fundamentavam-se nas práticas de pesquisa com o uso das fontes históricas, uma vez que, desde os primeiros anos escolares, o aluno construía sua trajetória de vida, incorporando o conceito de sujeito histórico, valorizando seus documentos como registros para a construção da sua história pessoal e da sociedade. Essa prática, que articula o ensino à pesquisa (ou vice-versa) desde os primeiros anos escolares, contribuiu para fortalecer significativamente o propósito da História nos projetos curriculares, ou seja: "a compreensão de si, dos outros e do lugar que ocupamos na sociedade". (NADAI, 1993, p. 160). 


\section{Referências Bibliográficas}

BITTENCOURT, Circe (org.). O saber histórico na sala de aula. São Paulo: Contexto, 2002.

FREIRE, Paulo. Educação e mudança. Rio de Janeiro: Paz e Terra, 1979.

NADAI, Elza. O ensino de história no Brasil: trajetória e perspectiva. In: Revista Brasileira de História. São Paulo, v.13, n.25/26, p. 143-162, set.1992/ago.1993.

SAVIANI, Dermeval. Pedagogia Histórico-crítica: primeiras aproximações. Campinas/São Paulo: Autores Associados, 2005.

SCHMIDT, Maria Auxiliadora; CAINELLI, Marlene. Ensinar História. São Paulo: Scipione, 2004.

SECRETARIA MUNICIPAL DE CURITIBA. Currículo Básico: uma contribuição para a Escola Pública Brasileira. Curitiba: Imprensa Oficial do Paraná, 1988. 